\title{
Structural investigations on bredigite from the Hatrurim Complex
}

\author{
Volker Kahlenberg $^{1}$ (D) $\cdot$ Irina Galuskina ${ }^{2} \cdot$ Biljana Krüger $^{1} \cdot$ Anuschka Pauluhn $^{3} \cdot$ Evgeny Galuskin $^{2}$
}

Received: 7 May 2018 / Accepted: 8 November 2018 / Published online: 20 November 2018

(C) The Author(s) 2018

\begin{abstract}
Bredigite, $\mathrm{Ca}_{7} \mathrm{Mg}\left(\mathrm{SiO}_{4}\right)_{4}$, is an indicator mineral of metasomatic rocks of the sanidinite facies formed at high temperatures $\left(>800{ }^{\circ} \mathrm{C}\right)$ and low pressures $(<1-2$ kbar). Bredigite samples from ternesite-gazeevite-larnite pyrometamorphic rocks of the Hatrurim Complex (Negev Desert, Israel) have been studied by electron probe micro analysis and single-crystal diffraction using synchrotron radiation. They are characterized by a relatively uniform composition. The empirical formula calculated on the basis of $16 \mathrm{O}$ atoms per formula unit is: $\left(\mathrm{Ca}_{7.006} \mathrm{Na}_{0.015} \mathrm{Ba}_{0.014}\right)_{\Sigma 7.035} \mathrm{Mg}_{0.938}\left(\mathrm{Si}_{4.000} \mathrm{P}_{0.014}\right)_{\Sigma 4.014} \mathrm{O}_{16}$. Basic crystallographic data of a sample studied by X-ray diffraction are as follows: orthorhombic symmetry, space group Pnnm, $a=18.38102(17) \AA, b=$ 6.74936(7) $\AA, c=10.90328(11) \AA, V=1352.66(2) \AA^{3}, Z=4$. Structure solution and subsequent least-squares refinements resulted in a residual of $\mathrm{R}(|\mathrm{F}|)=0.023$ for 2584 independent observed reflections with $I>2 \sigma(\mathrm{I})$ and 149 parameters. To the best of our knowledge this is the first detailed structural investigation on natural bredigite. In contrast to previous studies on samples retrieved from metallurgical slags there was no need to describe the structure in the acentric space group Pnn2. Furthermore, the problem of $\mathrm{Ba}$ incorporation into the bredigite structure is discussed. Data on the composition of Ba-bearing bredigites from pyrometamorphic rocks of the Hatrurim Complex from Jordan with simplified formula $\mathrm{Ba}_{0.7} \mathrm{Ca}_{13.3} \mathrm{Mg}_{2}\left(\mathrm{SiO}_{4}\right)_{8}$ (based on 32 oxygen atoms) are provided for the first time, pointing out perspectives of finding new Ba-bearing minerals isostructural with bredigite in nature.
\end{abstract}

Keywords Bredigite $\cdot$ Crystal structure $\cdot$ Pyrometamorphic rocks $\cdot$ Barium $\cdot$ Hatrurim

\section{Introduction}

Bredigite (idealized chemical composition $\left.\mathrm{Ca}_{7} \mathrm{Mg}\left(\mathrm{SiO}_{4}\right)_{4}\right)$ is a rare mineral that has been described from petrological settings related to pyrometamorphism (Grapes 2011). It has been observed, for example, in contact-metamorphized rocks or in altered carbonate-silicate xenoliths within volcanites based on siliceous limestone-dolomite protoliths.

Characteristic localities for this type of occurrence are Scawt Hill, Northern Ireland (Tilley and Vincent 1948;

Editorial handling: H. Poellmann

Volker Kahlenberg

volker.kahlenberg@uibk.ac.at

1 Institute of Mineralogy and Petrography, University of Innsbruck, Innrain 52, A-6020 Innsbruck, Austria

2 Faculty of Earth Sciences, University of Silesia, Będzińska 60, 41-200 Sosnowiec, Poland

3 Paul Scherrer Institute/SLS, CH-5232 Villigen, Switzerland
Sabine et al. 1985) or the Christmas Mountains, Texas (Joesten 1976).

In pyrometamorphic rocks of the Hatrurim Complex consisting of products of combustion metamorphism, we and other researchers (Gross 1977; Sharygin et al. 2008; Sokol et al. 2010; Vapnik and Vardi 2013) repeatedly noted small bredigite grains, mainly, in larnite rocks. The Hatrurim Complex is distributed over a wide area along the Dead Sea rift zone in the territories of Israel, Palestine and Jordan (Bentor 1960; Gross 1977; Vapnik et al. 2007; Novikov et al. 2013). Its formation was driven by combustion processes of a sedimentary protolith, however, the detailed genesis of the Hatrurim Complex is still under discussion (Sokol et al. 2010; Kolodny et al. 2013; Vapnik and Novikov 2013). The main hypothesis is pyrometamorphic rock-formation due to combustion of organic matter contained in primary sedimentary rocks (Kolodny and Gross 1974; Matthews and Gross 1980; Geller et al. 2012). Recently, a "mud-volcanic" hypothesis has been proposed, suggesting high-temperature pyrometamorphic alteration of primary rocks driven by methane fire exhaling from tectonic active zones of the Dead Sea rift (Sokol et al. 2010; Novikov et al. 2013). 
There are a few classes of pyrometamorphic rocks in the Hatrurim Complex, including gehlenite hornfelses, larnite pseudoconglomerates and spurrite marbles, and also melted rocks (paralavas) of several types (Gross 1977; Vapnik et al. 2007). Rocks containing more exotic minerals such as ternesite, silicocarnotite, nabimusiate, gazeevite, jasmundite, fluorkyuygenite are less abundant. Their formation is related to processes of high-temperature alteration of early clinker-like mineral associations under the influence of combustion by-products (gases, fluids) in the course of pyrometamorphism (Galuskina et al. 2014; Galuskin et al. 2016). Relatively large bredigite grains suitable for structural investigations are the objects of this work and were found in unusual ternesite-gazeevite-larnite rocks in the Negev Desert, Israel.

Practically in all known localities, bredigite forms small, twinned and often intensely altered grains (Armbruster et al. 2011; Galuskina et al. 2015). Probably, this is the reason for the lack of structural investigations on natural single-crystals so far.

Apart from being a mineralogical curiosity, bredigite is also of interest for the field of material science and has been intensively studied as a host for rare earth elements for synthesis of new photoluminescent compounds (Lee et al. 2012; Jia et al. 2012; Zhang and Jiang 2014; Sun et al. 2015). In addition, research on bredigite included areas as diverse as bioactive ceramics (Wu et al. 2005; Huang and Chang 2008; Rahmati et al. 2018), steelmaking slags (Wang et al. 2015; Kriskova et al. 2018) or chemical stabilizing of radioactive waste (Jantzen et al. 1984).

Lin and Foster (1975) placed the upper stability limit of bredigite at $1372{ }^{\circ} \mathrm{C}$ where it starts to decompose into $\mathrm{Ca}_{2} \mathrm{SiO}_{4}$ and $\mathrm{Ca}_{3} \mathrm{Mg}\left(\mathrm{SiO}_{4}\right)_{2}$. According to Essene (1980) the question of the lower stability is not resolved. The value of $979{ }^{\circ} \mathrm{C}$ reported by Schlaudt and Roy (1966) may actually represent rather a synthesis than an equilibrium boundary.

Notably, when comparing morphological and optical properties of natural and synthetic samples, Tilley and Vincent (1948) postulated that bredigite is isostructural with $\alpha^{\prime}-\mathrm{Ca}_{2} \mathrm{SiO}_{4}$. More detailed crystallographic investigations on the same samples were subsequently performed by Douglas (1952). Focusing on the orthorhombic unit-cell parameters $(a=10.93 \AA, b=6.75 \AA, c=18.41 \AA)$ she recognized a close resemblance to the values previously reported for $\alpha^{\prime}-\mathrm{Ca}_{2} \mathrm{SiO}_{4}$. However, two lattice parameters found for bredigite were approximately twice those of the pure calcium silicate. Saalfeld (1974) confirmed the orthorhombic cell. Based on electron microprobe analysis he determined that the chemical formula of this phase is $\mathrm{Ca}_{7} \mathrm{Mg}\left(\mathrm{SiO}_{4}\right)_{4}$. The trials and tribulations of the bredigite $-\alpha^{\prime}-\mathrm{Ca}_{2} \mathrm{SiO}_{4}$ interrelationship have been summarized by Moseley and Glasser (1981). A complete structure determination of bredigite was eventually presented by Moore and Araki (1976). They came to the conclusions that (i) bredigite is a stoichiometric compound with idealized composition $\mathrm{Ca}_{7} \mathrm{Mg}\left(\mathrm{SiO}_{4}\right)_{4}$ (or $\mathrm{Ca}_{1.75} \mathrm{Mg}_{0.25} \mathrm{SiO}_{4}$ ) and (ii) $\alpha$ $\mathrm{Ca}_{2} \mathrm{SiO}_{4}$ and bredigite are not isostructural. Based on Moore's landmark paper on relations between different orthosilicates and sulfates (Moore 1973) a detailed topological analysis of bredigite was given as well.

Interestingly, Moore used the same synthetic sample of Tilley and Vincent from 1948 which had been obtained from a metallurgical slag of the so-called spiegeleisen production. The German word spiegeleisen (literally "mirror iron") is a technical term that found its way into the English language and describes a ferromanganese alloy containing small quantities of carbon and silicon. Therefore, it is not surprising that chemical analysis of the abovementioned sample revealed the presence of manganese in the crystal structure, substituting for magnesium.

The present contribution reports the first results of detailed chemical and crystallographic investigations of natural bredigite samples retrieved from the Hatrurim Complex.

\section{Experimental details}

The chemical composition of bredigite was measured using an electron microprobe analyzer CAMECA SX100 (Institute of Geochemistry, Mineralogy and Petrology, University of Warsaw, Poland). Electron probe microanalyses were performed at $15 \mathrm{kV}, 10 \mathrm{nA}$ and a beam diameter of about $1 \mu \mathrm{m}$, using the following lines and standards: $\mathrm{Na}-K_{\alpha}$ : albite; $\mathrm{Mg}$ $K_{\alpha}, \mathrm{Ca}-K_{\alpha}, \mathrm{Si}-K_{\alpha}$ : diopside; Ba- $L_{\alpha}$ : barite, P- $K_{\alpha}$ : apatite; Fe$K_{\alpha}$ : hematite; Al- $K_{\alpha}, \mathrm{K}-K_{\alpha}$ : orthoclase; Ti- $K_{\alpha}$ : rutile; $\mathrm{Mn}-K_{\alpha}$ : rhodochrosite, $\mathrm{V}-K_{\alpha}: \mathrm{V}_{2} \mathrm{O}_{5} ; \mathrm{Sr}-L_{\alpha}: \mathrm{SrTiO}_{3}$.

Samples for the single-crystal diffraction studies were screened with a petrographic microscope. Finally, a crystal showing sharp extinction when observed under crossed polarizers was selected and mounted on a loop using epoxy resin. The diffraction experiment was performed on the X06DA beamline at the Swiss Light Source, Paul Scherrer Institute, Villigen, Switzerland. Diffraction data were collected at $25{ }^{\circ} \mathrm{C}$ using the DA+ acquisition software and a Pilatus $2 \mathrm{M}-\mathrm{F}$ detector in shutterless operation at a wavelength of $0.70848 \AA(=17.5 \mathrm{keV})$. The detector was placed $80 \mathrm{~mm}$ from the sample, without a vertical offset, resulting in a maximum resolution of $0.7 \AA .1800$ frames were recorded using fine-sliced $\left(0.1^{\circ}\right) \omega$-scans with $0.2 \mathrm{~s}$ per frame. Table 1 contains a summary of the conditions pertaining to data collection. The CrysAlis ${ }^{\text {PRO }}$ software package (Rigaku Oxford Diffraction 2015) was employed to process the data. After indexing, the diffraction patterns were integrated. Further data reduction included Lorentz and polarization corrections as well as an absorption correction based on spherical harmonics. Diffraction symmetry of the crystal conformed to the 
Table 1 Crystal data and structure refinement. The formula refers to the results of the crystal structure analysis

\begin{tabular}{|c|c|}
\hline Empirical formula & $\mathrm{Ca}_{6.97} \mathrm{Ba}_{0.03} \mathrm{Mg}\left(\mathrm{SiO}_{4}\right)_{4}$ \\
\hline Formula weight (g/Mol) & 676.14 \\
\hline Temperature $(\mathrm{K})$ & $295(2)$ \\
\hline Wavelength $(\AA)$ & 0.70848 \\
\hline Crystal system & orthorhombic \\
\hline Space group & Pnnm \\
\hline \multirow[t]{3}{*}{ Unit cell dimensions $(\AA)$} & $a=18.38102(17)$ \\
\hline & $b=6.74936(7)$ \\
\hline & $c=10.90328(11)$ \\
\hline Volume $\left(\AA^{3}\right)$ & $1352.66(2) \AA^{3}$ \\
\hline$Z$ & 4 \\
\hline Density (calculated, $\mathrm{Mg} / \mathrm{m}^{3}$ ) & 3.32 \\
\hline Absorption coefficient $\left(\mathrm{mm}^{-1}\right)$ & 3.24 \\
\hline $\mathrm{F}(000)$ & 1348.2 \\
\hline Crystal size $\left(\mathrm{mm}^{3}\right)$ & $0.04 \times 0.04 \times 0.03$ \\
\hline$\theta$-range for data collection $\left(^{\circ}\right)$ & 2.16 to 33.98 \\
\hline Index ranges & $-27 \leq \mathrm{h} \leq 28,-8 \leq \mathrm{k} \leq 9,-15 \leq 1 \leq 15$ \\
\hline Reflections collected & 19,247 \\
\hline Independent reflections & $2584\left[\mathrm{R}_{\mathrm{int}}=0.0312\right]$ \\
\hline Refinement method & Full-matrix least-squares on $\mathrm{F}^{2}$ \\
\hline Data / restraints / parameters & $2584 / 0 / 149$ \\
\hline Goodness-of-fit on $\mathrm{F}^{2}$ & 1.163 \\
\hline Final $R$ indices $[\mathrm{I}>2 \sigma(\mathrm{I})]$ & $R 1=0.0231, w R 2=0.0656$ \\
\hline $\mathrm{R}$ indices (all data) & $R 1=0.0234, w R 2=0.0659$ \\
\hline Extinction coefficient & $0.0026(2)$ \\
\hline Largest diff. Peak and hole (e. $\left.\AA^{-3}\right)$ & 0.73 and -0.67 \\
\hline
\end{tabular}

orthorhombic Laue group $2 / m 2 / m 2 / m$. Systematic absences were compatible with the space groups $P 2_{1} / n 2_{1} /$ $n 2 / m$ (Pnnm) or Pnn2, respectively.

Refinement calculations were performed using the program SHELX-97 (Sheldrick 2008) implemented in the WinGX software package (Farrugia 1999). X-ray scattering factors for neutral atoms were taken from the International Tables for Crystallography, Vol. C (Wilson 1992). After transformation to standard setting, structure refinement was initiated from the atomic coordinates reported by Moore and Araki (1976) in the acentric space group Pnn2. This model rapidly converged to a residual of $\mathrm{R}(|\mathrm{F}|)=0.023$ (266 parameters). Validation of the structure was accomplished using the program PSEUDO (Capillas et al. 2011). It turned out that the atomic coordinates fulfilled the symmetry requirements of Pnnm and, therefore, the final calculations were conducted in the centrosymmetric space group. The updated model converged to $\mathrm{R}(|\mathrm{F}|)=0.023$ (149 parameters), i.e. the residuals of the refinements in Pnnm and $P n n 2$ are identical, though the number of parameters in Pnnm is roughly halved. We shall present a more detailed analysis of the relationships between the Pnn2 and Pnnm structures further on in the Discussion section.
Within three standard uncertainties, site population refinements indicated full occupancy for most of the different $\mathrm{Ca}$ - and $\mathrm{Mg}$-positions in the asymmetric unit of the centrosymmetric structure. Ca1, however, exhibited a slightly but significantly increased scattering density. Since chemical analysis proved the presence of a small amount of barium, we attributed this observation to a $\mathrm{Ca}-\mathrm{Ba}$ substitution on this site. The corresponding $\mathrm{Ca} / \mathrm{Ba}$ content was determined from a site occupancy refinement where the total amount of both alkaline earth ions on this position was constraint to $100 \%$. The optimized atomic coordinates, equivalent isotropic and anisotropic displacement factors as well as selected interatomic distances and angles are given in Tables 2, 3 and 4. Figures showing structural details were prepared using the program VESTA (version 3.1.2) (Momma and Izumi 2011).

\section{Results}

\section{Occurrence and material description}

From a petrological point of view, the rock samples studied in this contribution are extremely unusual. They can be 
Table 2 Relative atomic coordinates and equivalent isotropic displacement parameters $\left(\AA^{2} \times 10^{3}\right) . U_{e q}$ is defined as one third of the trace of the orthogonalized $U_{\mathrm{ij}}$ tensor. $\mathrm{Ca} / \mathrm{Ba} 1$ shows a mixed $\mathrm{Ca}-\mathrm{Ba}$ occupancy: $94.0(2) \% \mathrm{Ca}+6.0(2) \% \mathrm{Ba}$

\begin{tabular}{|c|c|c|c|c|c|}
\hline Atom & Wyckoff-position & $\mathrm{x}$ & $\mathrm{y}$ & $\mathrm{Z}$ & $U_{e q}$ \\
\hline $\mathrm{Ca} / \mathrm{Ba} 1$ & $2 a$ & 0 & 0 & 0 & $34.1(2)$ \\
\hline $\mathrm{Ca} 2$ & $2 b$ & 0 & 0 & 0.5 & $19.17(12)$ \\
\hline $\mathrm{Ca} 3$ & $8 h$ & $0.22735(1)$ & $0.00132(3)$ & $0.23162(2)$ & $7.83(7)$ \\
\hline $\mathrm{Ca} 4$ & $8 h$ & $0.41182(1)$ & $0.15785(4)$ & $0.25126(2)$ & $12.19(7)$ \\
\hline $\mathrm{Ca} 5$ & $4 g$ & $0.17338(2)$ & $0.32849(5)$ & 0 & $12.32(8)$ \\
\hline $\mathrm{Ca} 6$ & $4 g$ & $0.16720(2)$ & $0.30221(5)$ & 0.5 & $12.91(8)$ \\
\hline Mg1 & $2 d$ & 0.5 & 0 & 0 & $7.4(2)$ \\
\hline Mg2 & $2 c$ & 0.5 & 0 & 0.5 & $6.48(14)$ \\
\hline Sil & $8 h$ & $0.08072(2)$ & $0.21925(5)$ & $0.74831(3)$ & $6.92(8)$ \\
\hline $\mathrm{Si} 2$ & $4 g$ & $0.16404(2)$ & $-.23548(6)$ & 0 & $6.31(9)$ \\
\hline $\mathrm{Si} 3$ & $4 g$ & $0.33807(2)$ & $0.28277(7)$ & 0 & $6.09(9)$ \\
\hline $\mathrm{O} 1$ & $8 h$ & $0.02476(5)$ & $0.28152(14)$ & $0.63841(8)$ & $15.81(17)$ \\
\hline $\mathrm{O} 2$ & $8 h$ & $0.05546(6)$ & $0.34105(17)$ & $0.87025(10)$ & $26.0(2)$ \\
\hline $\mathrm{O} 3$ & $8 h$ & $0.16108(4)$ & $0.31041(13)$ & $0.71410(8)$ & $10.76(15)$ \\
\hline $\mathrm{O} 4$ & $8 h$ & $0.08870(6)$ & $-.01097(14)$ & $0.78108(10)$ & $17.17(19)$ \\
\hline O5 & $8 h$ & $0.19717(5)$ & $-.34745(14)$ & $-.12011(8)$ & $14.20(16)$ \\
\hline O6 & $4 g$ & $0.07712(6)$ & $-.2735(2)$ & 0 & $14.1(2)$ \\
\hline $\mathrm{O} 7$ & $4 g$ & $0.19466(8)$ & $-.0117(2)$ & 0 & $16.0(2)$ \\
\hline O8 & $8 h$ & $0.28859(5)$ & $0.25633(13)$ & $-.12201(7)$ & $13.48(16)$ \\
\hline O9 & $4 g$ & $0.39785(6)$ & $0.1042(2)$ & 0 & $14.9(2)$ \\
\hline $\mathrm{O} 10$ & $4 g$ & $0.37626(7)$ & $0.49606(18)$ & 0 & $13.2(2)$ \\
\hline
\end{tabular}

Table 3 Anisotropic displacement parameters $\left(\AA^{2} \times 10^{3}\right)$. The anisotropic displacement factor exponent takes the form: $-2 \pi^{2}$ $\left[\mathrm{h}^{2} \mathrm{a}^{* 2} U_{11}+\ldots+2 \mathrm{hka} * \mathrm{~b} * U_{12}\right]$

\begin{tabular}{lllllll}
\hline Atom & $U_{11}$ & $U_{22}$ & $U_{33}$ & $U_{23}$ & $U_{13}$ & $U_{12}$ \\
\hline $\mathrm{Ca} / \mathrm{Ba} 1$ & $22(1)$ & $14(1)$ & $66(1)$ & 0 & 0 & $9(1)$ \\
$\mathrm{Ca} 2$ & $11(1)$ & $8(1)$ & $39(1)$ & 0 & 0 & $-2(1)$ \\
$\mathrm{Ca} 3$ & $8(1)$ & $6(1)$ & $9(1)$ & $1(1)$ & $0(1)$ & $0(1)$ \\
$\mathrm{Ca} 4$ & $13(1)$ & $7(1)$ & $16(1)$ & $2(1)$ & $3(1)$ & $0(1)$ \\
$\mathrm{Ca} 5$ & $12(1)$ & $7(1)$ & $18(1)$ & 0 & 0 & $1(1)$ \\
$\mathrm{Ca} 6$ & $20(1)$ & $9(1)$ & $9(1)$ & 0 & 0 & $1(1)$ \\
$\mathrm{Mg} 1$ & $6(1)$ & $7(1)$ & $9(1)$ & 0 & 0 & $1(1)$ \\
$\mathrm{Mg} 2$ & $7(1)$ & $7(1)$ & $6(1)$ & 0 & 0 & $0(1)$ \\
$\mathrm{Si} 1$ & $7(1)$ & $5(1)$ & $9(1)$ & $0(1)$ & $1(1)$ & $1(1)$ \\
$\mathrm{Si} 2$ & $6(1)$ & $5(1)$ & $8(1)$ & 0 & 0 & $-1(1)$ \\
$\mathrm{Si3}$ & $7(1)$ & $5(1)$ & $7(1)$ & 0 & 0 & $0(1)$ \\
O1 & $11(1)$ & $16(1)$ & $20(1)$ & $9(1)$ & $-3(1)$ & $1(1)$ \\
O2 & $30(1)$ & $23(1)$ & $25(1)$ & $-14(1)$ & $18(1)$ & $-6(1)$ \\
O3 & $8(1)$ & $12(1)$ & $13(1)$ & $0(1)$ & $0(1)$ & $-2(1)$ \\
O4 & $17(1)$ & $7(1)$ & $27(1)$ & $5(1)$ & $-4(1)$ & $1(1)$ \\
O5 & $16(1)$ & $15(1)$ & $12(1)$ & $-3(1)$ & $4(1)$ & $2(1)$ \\
O6 & $8(1)$ & $12(1)$ & $23(1)$ & 0 & 0 & $-2(1)$ \\
O7 & $21(1)$ & $8(1)$ & $20(1)$ & 0 & 0 & $-6(1)$ \\
O8 & $18(1)$ & $12(1)$ & $11(1)$ & $3(1)$ & $-7(1)$ & $-5(1)$ \\
O9 & $9(1)$ & $9(1)$ & $27(1)$ & 0 & 0 & $2(1)$ \\
O10 & $13(1)$ & $8(1)$ & $19(1)$ & 0 & 0 & $-4(1)$ \\
\hline
\end{tabular}

denominated as a larnite-ye'elimite-fluorellestadite hornfels, in the fine-grained matrix of which relatively large, elongated poikilitic ternesite $\mathrm{Ca}_{5}\left(\mathrm{SiO}_{4}\right)_{2}\left(\mathrm{SO}_{4}\right)$ crystals (metacrysts) can be found (Fig. 1a). Some parts are unevenly enriched in gazeevite $\mathrm{BaCa}_{6}\left(\mathrm{SiO}_{4}\right)_{2}\left(\mathrm{SO}_{4}\right)_{2} \mathrm{O}$ metacrysts up to $0.4 \mathrm{~cm}$ in size (Fig. 1a). Where gazeevite is absent, elongated merwinite $\mathrm{Ca}_{3} \mathrm{Mg}\left(\mathrm{SiO}_{4}\right)_{2}$ metacrysts occur (Fig. 1b). Bredigite is present as xenomorphic poikilitic crystals, in which ye'elimite inclusions are substituted by hydrogrossular. Notably, in the grayscale range of the back scattered electrons (BSE) images bredigite and larnite grains look very similar. However, thanks to the dark hydrogrossular inclusions they can be easily differentiated (Fig. 1a, c). Bredigite metacrysts without any inclusions are very rare (Fig. 1c, d). The color of the rock samples is brown due to small inclusions of minerals such as perovskite or the magnesioferrite-spinel series. Rounded black aggregates of hematite and magnesioferrite (up to $1 \mathrm{~cm}$ ) with scarce harmunite inclusions occur in the rock rarely.

The bredigite-bearing rocks were found in the Negev Desert near Arad city, Israel. They occur at the contact with brecciated, carbonatized and zeolitized diopsideandradite-wollastonite rocks (probably belonging to the so-called "olive" paralava series, Vapnik et al. 2007) with abundance of baryte and hematite. The thickness of the bredigite-bearing rock does not exceed several tens of 


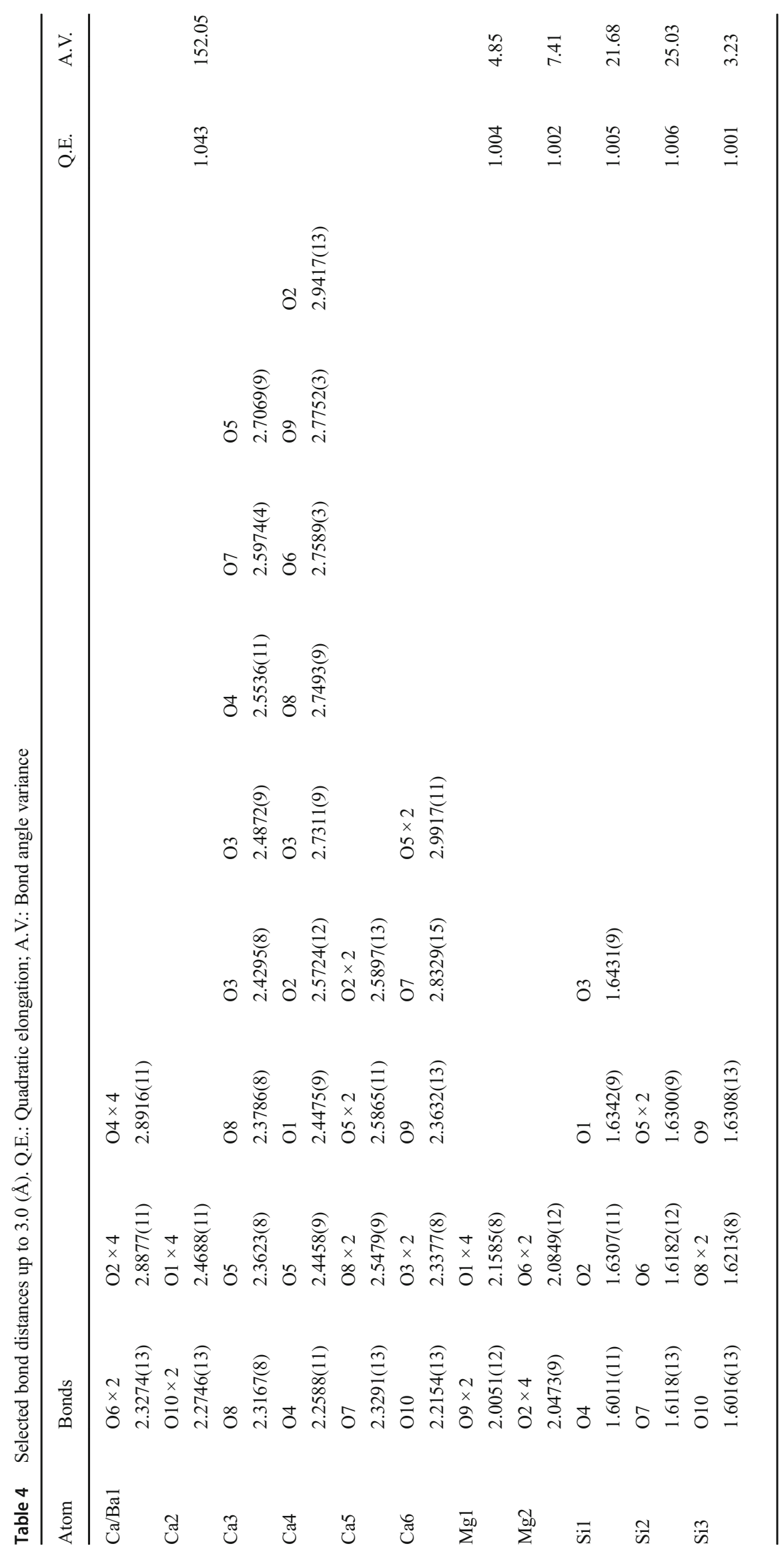


Fig. 1 Fine-grained larniteye'elimite hornfels from the Hatrurim Complex (Negev Desert, Israel): a - with poikilitic gazeevite, ternesite and bredigite crystals. b - gazeevite-free fragments with merwinite metacrysts; $\mathbf{c}$ - fragments with gazeevite and bredigite poikilitic crystals; $\mathbf{d}$ - intergrowth of bredigite crystals, which are purged of ye'elimite inclusions (black) during crystal growth. $\mathrm{Brg}=$ bredigite, Els = fluorellestadite, $\mathrm{Gzv}=$ gazeevite, $\mathrm{Lrn}=$ larnite, $\mathrm{Mfr}=$ magnesioferrite, $\mathrm{Mw}=$ merwinite, $\operatorname{Trn}=$ ternesite, $\mathrm{Ye}=$ ye'elimite
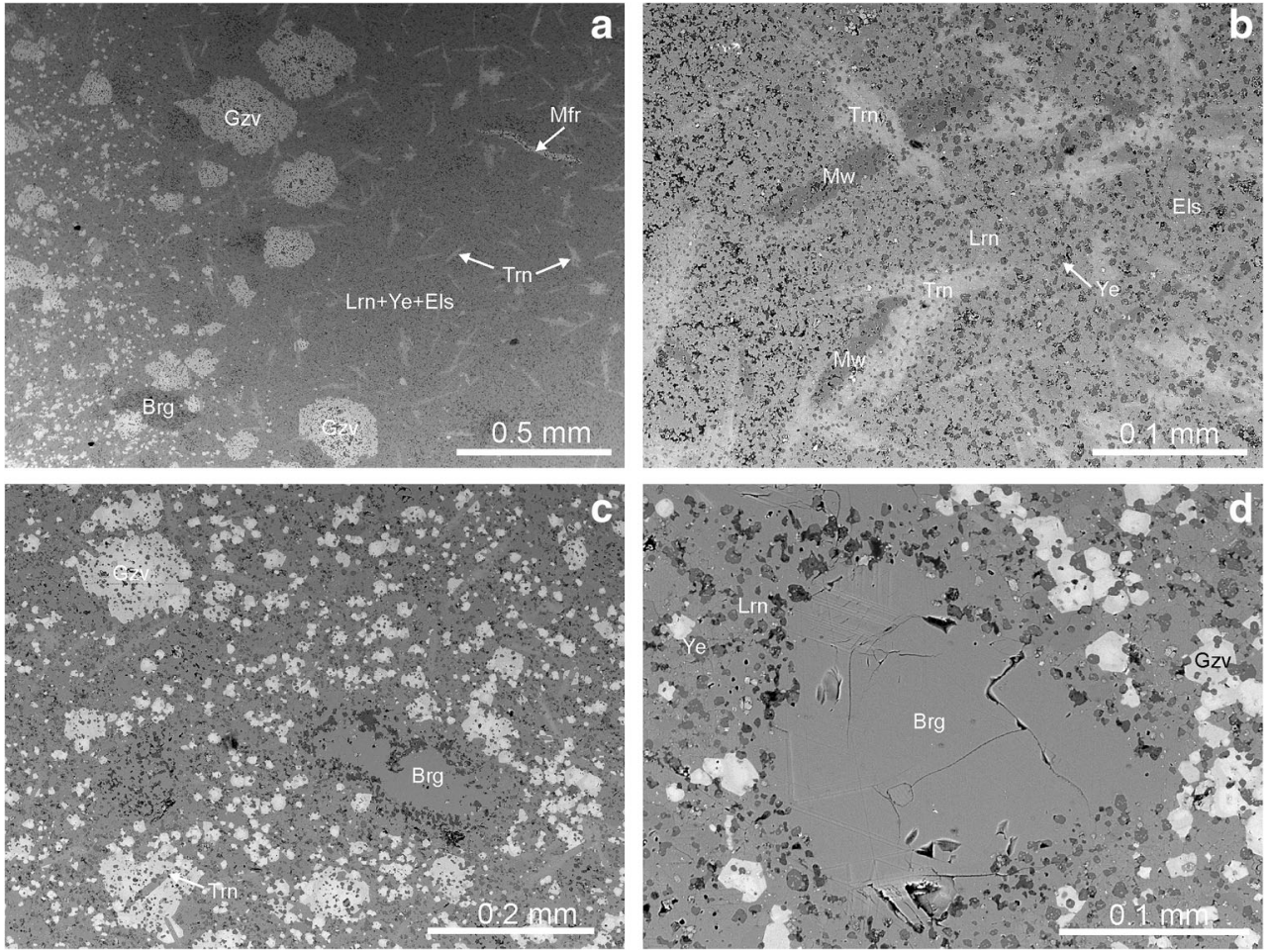

centimeters. It can be assumed, that the fine-grained rocks containing the clinker-like larnite-ye'elimite-fluorellestadite association formed at the pyrometamorphism peak as a result of transformations in a relatively dry isochemical system. The rocks provided a substrate for later mineral assemblages of poikilitic crystals of ternesite, merwinite, gazeevite and bredigite (see Fig. 1). For the formation of poikilitic crystals (metacrysts), the presence of a fluid and a capillary system where dissolution and crystallization processes can take place is a pre-requisite (Beus 1962). Bredigite metacryst growth was accompanied with removing of ye'elimite inclusions, a mechanism that resulted in relatively pure material suitable for our investigations (Fig. 1d). Closely spaced combustion foci can be sources of high-temperature fluids. The activity of these foci is reflected by the presence of melted rocks nearby.

In Fig. 1d, a bredigite intergrowth is shown, from which the fragment used for single-crystal X-ray diffraction investigation was retrieved. Bredigite is characterized by a relatively uniform composition, $\left(\mathrm{Ca}_{7.006} \mathrm{Na}_{0.015} \mathrm{Ba}_{0.014}\right)_{\Sigma 7.035} \mathrm{Mg}_{0.938}\left(\mathrm{Si}_{4.000} \mathrm{P}_{0.014}\right)_{\Sigma 4.014} \mathrm{O}_{16}$, close to the composition of the ideal end-member (Table 5). As a result of the structure refinement, a slightly higher Ba content of ca. 0.03 Ba atoms p.f.u. was obtained (Table 1). Most likely, intergrowth and twin boundaries of the bredigite grains are somewhat richer in $\mathrm{Ba}$, but these areas are not routinely analyzed by electron microprobe. In the BSE image fine twinning of bredigite is clearly visible (Fig. 1d).

\section{Crystal-structure analysis}

Bredigite belongs to the group of orthosilicates. Three crystallographically different $\left[\mathrm{SiO}_{4}\right]$-tetrahedra can be distinguished in the asymmetric unit. The spread of the Si-O bond distances and $\mathrm{O}-\mathrm{Si}-\mathrm{O}$ angles in these polyhedra is not very pronounced, resulting in low values for the quadratic elongations and bond angle variances (see Table 4). Both parameters can be conveniently used for numerical quantification of the distortions (Robinson et al. 1971). Linkage between the tetrahedra is provided by alkaline earth cations showing variable coordination numbers between 6 and 10. Two octahedrally coordinated sites in the asymmetric unit are occupied with $\mathrm{Mg}$. The coordination polyhedron about $\mathrm{Ca} 2$ can be described as an octahedron (trigonal antiprism) as well, though its degree of distortion is larger than that of the $\left[\mathrm{MgO}_{6}\right]$-units (see Table 4). Barium replacement for calcium is restricted to the site with the largest average cation - anion bond distances also showing the largest number of next oxygen neighbors. Its coordination figure could be approximated as a strongly distorted octahedron with four additional $\mathrm{Ca} / \mathrm{Ba}-\mathrm{O}$ bonds. $\mathrm{A}$ projection of the whole crystal structure parallel to [010] is presented in Fig. 2.

As already pointed out by Moore and Araki (1976), pinwheel-like clusters consisting of a central $\left[\mathrm{MgO}_{6}\right]$-octahedron and six attached $\left[\mathrm{SiO}_{4}\right]$-tetrahedra are characteristic building blocks of bredigite. As can be seen in Fig. 3, the sequence of directedness, i.e. the sequence of up (u) and down (d) pointing tetrahedra within a cluster is ududud. Using the 
Table 5 Chemical compositions of bredigite from Israel (sample 1, average of 9 spot analyses) and "Ba-Ca-bredigite" from Jordan (sample 2, average of 14 spot analyses)

\begin{tabular}{|c|c|c|c|c|c|c|c|c|}
\hline & \multicolumn{4}{|c|}{ Sample 1} & \multicolumn{4}{|c|}{ Sample 2} \\
\hline & Wt. $\%$ & s.d. & Range & a.p.f.u.* & Wt.\% & s.d. & Range & a.p.f.u. ${ }^{* *}$ \\
\hline $\mathrm{P}_{2} \mathrm{O}_{5}$ & 0.14 & 0.06 & $0.03-0.21$ & 0.014 & 0.84 & 0.16 & $0.68-1.21$ & 0.167 \\
\hline $\mathrm{SiO}_{2}$ & 35.16 & 0.20 & $34.81-35.59$ & 4.000 & 32.93 & 0.22 & $32.49-33.25$ & 7.713 \\
\hline $\mathrm{TiO}_{2}$ & n.d. & & & & 0.16 & 0.03 & $0.11-0.23$ & 0.027 \\
\hline $\mathrm{Al}_{2} \mathrm{O}_{3}$ & n.d. & & & & 0.17 & 0.02 & $0.12-0.20$ & 0.046 \\
\hline $\mathrm{Fe}_{2} \mathrm{O}_{3}$ & 0.07 & 0.06 & $0-0.20$ & 0.000 & 0.31 & 0.07 & $0.21-0.46$ & 0.055 \\
\hline $\mathrm{MgO}$ & 5.53 & 0.10 & $5.29-5.67$ & 0.938 & 5.35 & 0.12 & $5.07-5.48$ & 1.867 \\
\hline $\mathrm{CaO}$ & 57.48 & 0.20 & $57.14-57.74$ & 7.006 & 53.14 & 0.28 & $52.96-53.85$ & 13.338 \\
\hline $\mathrm{MnO}$ & n.d. & & & & 0.13 & 0.05 & $0.02-0.19$ & 0.025 \\
\hline $\mathrm{SrO}$ & n.d. & & & & 0.30 & 0.05 & $0.20-0.38$ & 0.040 \\
\hline $\mathrm{BaO}$ & 0.31 & 0.03 & $0.26-0.37$ & 0.014 & 6.89 & 0.36 & $6.27-7.39$ & 0.632 \\
\hline $\mathrm{Na}_{2} \mathrm{O}$ & 0.07 & 0.02 & $0.03-0.10$ & 0.015 & 0.09 & 0.02 & $0.06-0.14$ & 0.041 \\
\hline $\mathrm{K}_{2} \mathrm{O}$ & n.d. & & & & 0.18 & 0.03 & $0.13-0.25$ & 0.054 \\
\hline Total & 98.77 & & & & 100.47 & & & \\
\hline
\end{tabular}

Calculated on $* 16 \mathrm{O}$ and $* * 32 \mathrm{O}$ p.f.u.; n.d. - below limit detection. Remark: Normalization on 32 oxygens p.f.u. for sample 2 allows for an easier comparison with the data on synthetic compounds published by Moseley and Glasser (1982) (see text) nomenclature of mixed tetrahedral-octahedral networks, the clusters can be considered as so-called polyhedral microensembles or PME's. According to the classification given by Ilyushin and Blatov (2002) based on the calculation of the coordination sequences up to $\mathrm{k}=3$, the PME's in bredigite can be denoted as $\{6,6,18\}$.
Fig. 2 Projection of the whole crystal structure of bredigite parallel to [010]. Small red and larger green spheres represent $\mathrm{O}$ and $\mathrm{Ca}$, respectively. The $\mathrm{Ca} / \mathrm{Ba} 1$ sites showing mixed occupancies are indicated in pink color. $\left[\mathrm{SiO}_{4}\right]$-tetrahedra and $\left[\mathrm{MgO}_{6}\right]-$ octahedra are shown in blue and orange

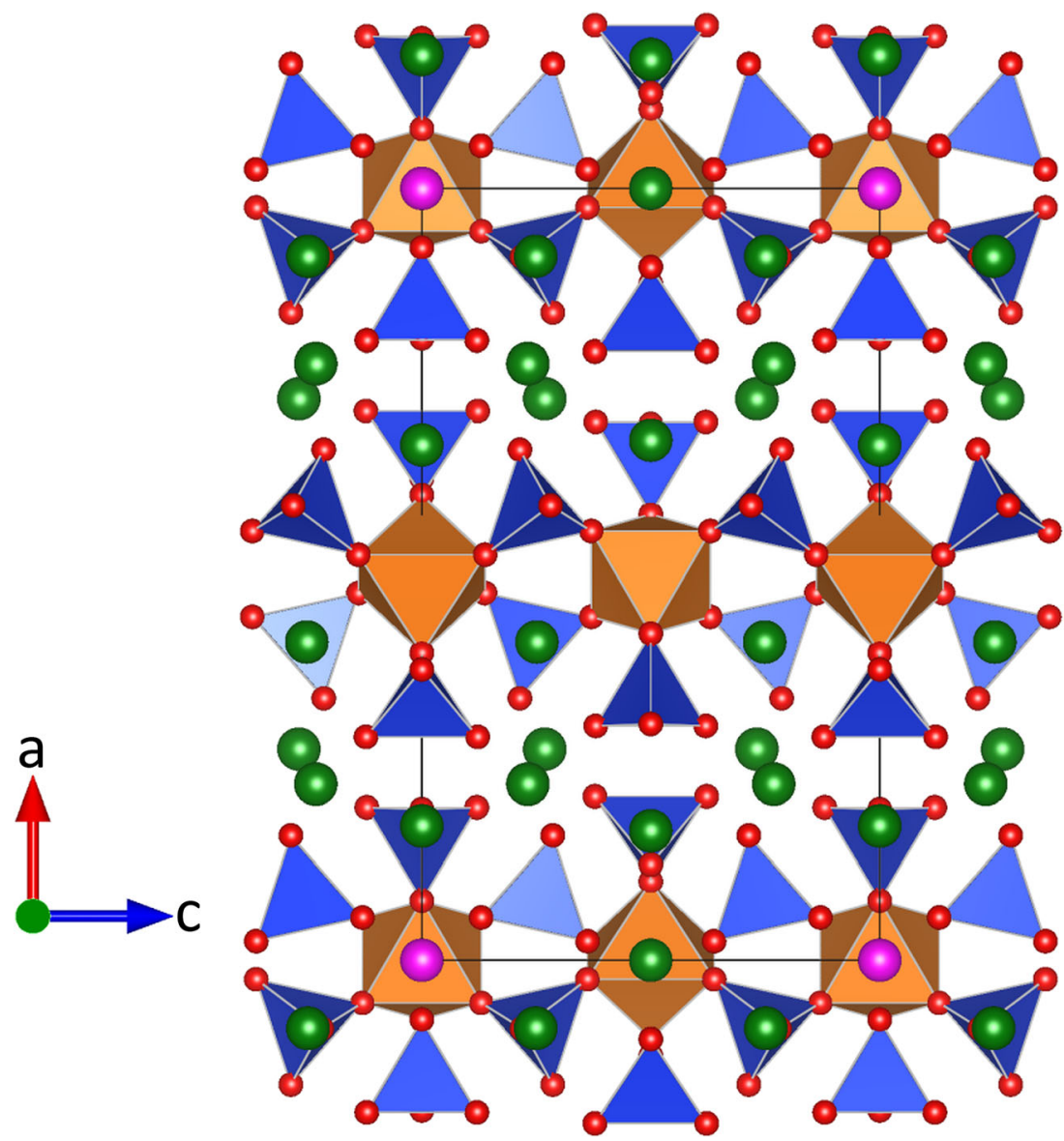




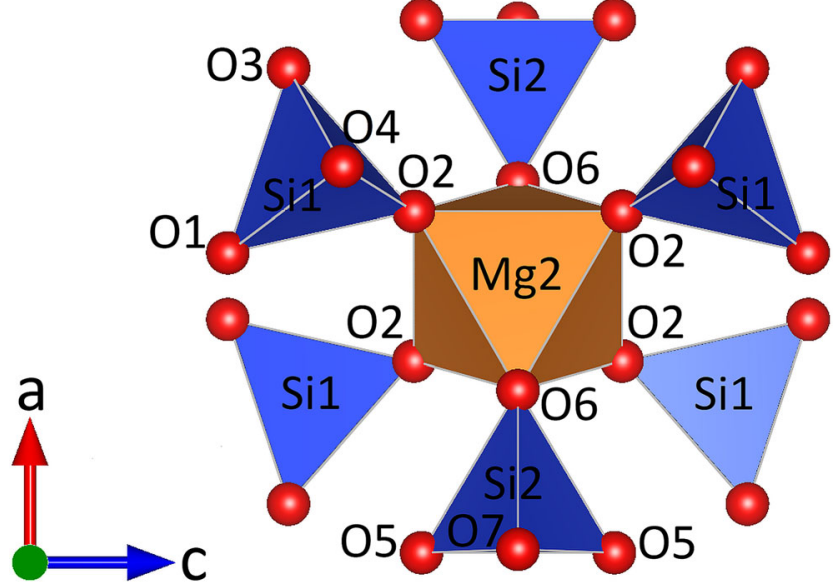

Fig. 3 Single "pinwheel" containing one $\left[\mathrm{MgO}_{6}\right]$-octahedron (about $\mathrm{Mg} 2$, site symmetry ..2/m) and six surrounding $\left[\mathrm{SiO}_{4}\right]$-tetrahedra

Neighboring pinwheels form chains running parallel to [001], where a single central $\left[\mathrm{MgO}_{6}\right]$-octahedron shares two tetrahedra on each side with the adjacent octahedra (see Fig. 2). The chains are located in about $7 \AA$ wide layers parallel to (100) (see Fig. 4) Proximate chains in a layer are connected by $\mathrm{Ca} / \mathrm{Ba} 1, \mathrm{Ca} 2$ and $\mathrm{Ca} 4$ whose coordination polyhedra exclusively involve oxygen atoms from the same layer. The layers in turn are linked by the remaining calcium positions $(\mathrm{Ca} 3, \mathrm{Ca} 5$ and $\mathrm{Ca} 6)$. A detailed analysis of the topological features of bredigite and its structural interrelationship to other orthosilicates and sulfates has been already presented by Moore and Araki (1976) and will not be repeated here.

A characteristic of the bredigite structure is a pronounced underbonding of the positions $\mathrm{Ca} / \mathrm{Ba} 1$ and $\mathrm{Ca} 5$, indicating that these cations are actually too small for their coordination environment. Bond valence sum (BVS) calculations using the parameter sets for $\mathrm{Ca}-\mathrm{O}$ and $\mathrm{Ba}-\mathrm{O}$ bonds published by Brown and Altermatt (1985) and $\mathrm{Ca} / \mathrm{Ba}-\mathrm{O}$ bonds up to $3.0 \AA$ A resulted in values of $1.53(\mathrm{Ca} / \mathrm{Ba} 1)$ and $1.62(\mathrm{Ca} 5)$ valence units (v.u.). Using the bond distances from the refinement of Moore and Araki (1976), we obtained similar strong deviations from the ideal values of 2 v.u., though the crystal structure was described in a lower symmetry. At this point we would like to mention that in the previous study the $\mathrm{Ca} / \mathrm{Ba}$ site (called $\mathrm{X} 11$ ) was suggested to be 12-coordinated, involving two additional distances of about $3.51 \AA$. The corresponding bond valences, however, are 0.02 v.u., i.e. from a stability point of view an inclusion of these two bonds can be hardly justified, though it helps for deciphering topological relationships with similar compounds (Moore 1973).

Notably, in chemically related structures such as merwinite $\left(\mathrm{Ca}_{3} \mathrm{Mg}\left(\mathrm{SiO}_{4}\right)_{2}\right.$ or $\left.\mathrm{Ca}_{1.5} \mathrm{Mg}_{0.5} \mathrm{SiO}_{4}\right)$ (Moore and Araki 1972) and hibonite $\left(\mathrm{CaAl}_{12} \mathrm{O}_{19}\right)$ (Kato and Saalfeld 1968) strongly underbonded alkaline earth positions with BVS as low as 1.66 or 1.50 , respectively, have been found as well.

\section{Discussion}

In order to study the question concerning the correct space group of bredigite in more detail, the Pnn2 model obtained from the initial refinement of our data was tested using the program PSEUDO (Capillas et al. 2011), accessible via the Bilbao Crystallographic Server. This program checks if a structure $\mathrm{S}$ of space group $\mathrm{H}$ is pseudosymmetric for a supergroup $\mathrm{G}>\mathrm{H}$. As a first step of the analysis, a left coset decomposition of $\mathrm{G}$ with respect to $\mathrm{H}$ is performed: $\mathrm{G}=\mathrm{e} \times \mathrm{H}+$ $\mathrm{g}_{2} \times \mathrm{H}+\ldots .+\mathrm{g}_{\mathrm{n}} \times \mathrm{H}$. The operations $\left\{\mathrm{e}, \mathrm{g}_{2}, \ldots, \mathrm{g}_{\mathrm{n}}\right\}$ are the coset representatives. Subsequently, the input structure $\mathrm{S}$ is transformed into the image $\mathrm{g}_{\mathrm{i}} \times \mathrm{S}$. Both structures are compared and in case that the shifts between corresponding atoms
Fig. 4 Projection of the whole crystal structure of bredigite parallel to [001]. The width of a single layer containing the pinwheel chains running along [001] is indicated by an arrow

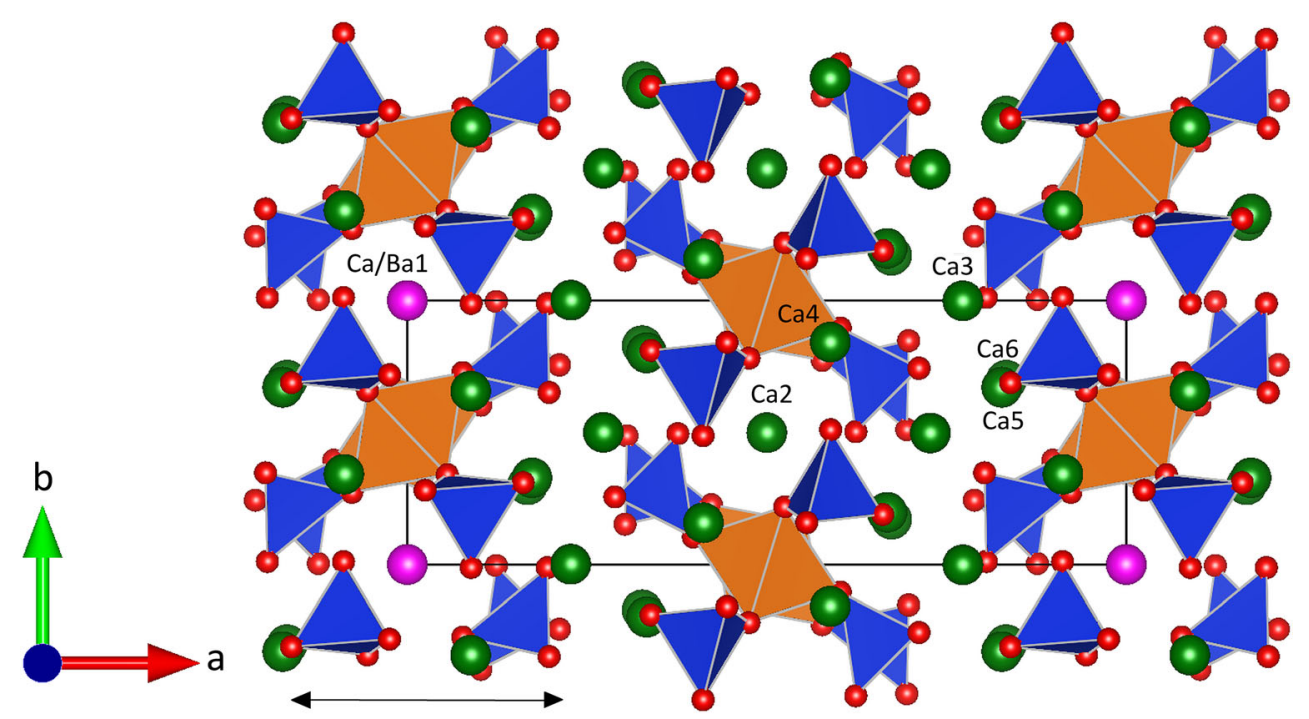


in $\mathrm{S}$ and $\mathrm{g}_{\mathrm{i}} \times \mathrm{S}$ are below a certain threshold, pseudosymmetry is indicated. In the present case, $\mathrm{H}=P n n 2$ and $\mathrm{G}=$ Pnnm. $\mathrm{H}$ is a translationengleiche subgroup of index two and, therefore, only one coset representative $g$ has to be considered. From the set of four potential representatives, $-x+1 / 2, y+1 / 2,-z+1 / 2$ (cor-

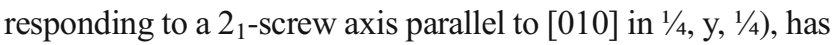
been selected. The resulting maximum displacement between the two structures $\mathrm{S}$ and $\mathrm{g} \times \mathrm{S}$ is $0.133 \AA$, i.e. the maximum deviation from centrosymmetry is half this value $(0.066 \AA)$. This clearly demonstrates that the crystal structures of the bredigite samples that we studied can be allocated to space group Pnnm. As expected, the analysis revealed that the number of atoms in the asymmetric unit of the structure when described in Pnnm has been reduced, due to the higher symmetry. Notably, however, for some positions the multiplicities did not change. A detailed list of the mappings between the corresponding atoms in Pnnm and Pnn2 is presented in Appendix 1 (Table 6). In the latter case the labeling scheme given in Moore and Araki (1976) was used.

The main difference between the structure determination of Moore and Araki (1976) performed on a slag sample and our analysis of a natural specimen results from the choice of space group symmetry. Their decision that the space group was $P n n 2$ resulted from the observation that in the centrosymmetric model "special positions on the mirror plane were misbehaving; there electron densities proceeded split across the mirror plane or merged into broad ellipsoidal contours". Therefore, one should expect that in Pnnm (i) the thermal displacement ellipsoids of the atoms located on $\mathrm{m}_{[001]}$ should exhibit a distinct prolate shape with their longest principal axes parallel to [001] and (ii) this effect should be less distinct (or even disappear) when a Pnn2 model is selected. A calculation of the ratio $\mathrm{U}_{3} /\left(\left(\mathrm{U}_{2}+\mathrm{U}_{1}\right) / 2\right)$ involving the values along the principal axes determined from our refined data of the anisotropic displacement parameters in Pnnm showed, that only in three cases these quotients were larger than $3: \mathrm{Ca} /$ Ba1 (3.6), Ca2 (4.2) and O9 (3.2). For all other atoms located on the mirror planes in $\mathrm{z}=0$ and $\mathrm{z}=1 / 2$ the ratios were between 0.7 and 2.3. In case of the $\mathrm{Ca} / \mathrm{Ba} 1$ site, for example, the distinct anisotropy may directly reflect the pronounced differences in size between the two substituting cation species. For the corresponding atoms of the first group the refinements in Pnn 2 resulted in similar deviations from isotropic behavior (X11: 3.5, X12: 4.0; O22-2: 3.5). In summary, we do not think that a symmetry reduction is justified - at least what concerns the natural sample that we studied.

In principle, significantly anisotropic thermal motions can be an indication for the presence of split positions. Therefore, we finally tested a model in Pnnm where the distinctly underbonded $\mathrm{Ca} / \mathrm{Ba} 1$ atoms are distributed among two split positions above and below the mirror plane. The refinement converged at a slightly higher residual when compared with the anisotropic approach $(\mathrm{R}(|\mathrm{F}|)=0.0326)$. In addition, the resulting shift of about $0.185 \AA$ away from $\mathrm{m}_{[001]}$ leads to only a very small increase of the bond valence sum (1.55 v.u.) for this site. Consequently, it was not deemed necessary to introduce split atoms into the Pnnm model.

The crystal chemistry of bredigite has been already studied to some extent using synthetic samples obtained from solid state reactions (Moseley and Glasser 1981, 1982). Notably, the preparation of phase-pure polycrystalline material is a rather sluggish process and requires many weeks with intermediate re-homogenization. Divalent cations such as $\mathrm{Zn}^{2+}$, $\mathrm{Co}^{2+}$ or $\mathrm{Ni}^{2+}$ could not be replaced for $\mathrm{Mg}$ between 1300 and $1350{ }^{\circ} \mathrm{C}$. It is well known that larger amounts of $\mathrm{Mn}$ can be found in bredigites from metallurgical slags. Quite surprisingly, however, the incorporation of $\mathrm{Mn}^{2+}$ by the abovementioned synthesis route was not possible either. Substitutions of larger alkaline earth cations $(\mathrm{Sr}, \mathrm{Ba})$ for $\mathrm{Ca}$ were more successful (Moseley and Glasser 1982) and cell parameters of potential bredigite-structured phases with general composition $\mathrm{XYCa}_{12} \mathrm{Mg}_{2}\left(\mathrm{SiO}_{4}\right)_{8}$ have been published, albeit there are indications that the so-called "Ba-Babredigite" (X,Y: Ba) has a slightly different structure (Moseley and Glasser 1982). A thorough re-investigation of this solid solution series would be definitely worthwhile.

All findings of bredigite in nature are related to hightemperature metasomatic rocks (Tilley and Vincent 1948; Sabine et al. 1985; Sokol et al. 2010; Grapes 2011; Armbruster et al. 2011; Galuskina et al. 2015). As mentioned above, bredigite is stable up to about $1372{ }^{\circ} \mathrm{C}$. Taking the relations between the minerals in the studied rocks into consideration (Fig. 1), it can be assumed that bredigite formed according to the known chemical reaction: $2 \mathrm{Ca}_{2} \mathrm{SiO}_{4}$ (larnite) $+\mathrm{Ca}_{4} \mathrm{Mg}\left(\mathrm{SiO}_{4}\right)_{2}$ (merwinite $)=\mathrm{Ca}_{7} \mathrm{Mg}\left(\mathrm{SiO}_{4}\right)_{4}$ (bredigite) (Grapes 2011). The formation of bredigite and gazeevite occurred simultaneously, i.e. both $\mathrm{Ba}$ and $\mathrm{S}$ were supplied to the mineral-forming system. Sulfur compounds can play a role as a catalyst and slightly reduce the crystallization temperature of bredigite, but this hypothesis needs confirmation.

Finally, what about the role of barium? So far, the only structure refinement of single-crystalline bredigite was made for a slag-sample (Moore and Araki 1976) with barium contents up to 6-7 wt.\% $\mathrm{BaO}$. Later investigations on natural bredigites, however, showed that barium was virtually absent (Sabine et al. 1985). Bredigite from the Negev Desert also exhibited low barium concentrations of about $0.3 \mathrm{wt} . \% \mathrm{BaO}$ (see Table 5). Recently, in larnite rocks of the Hatrurim Complex (Daba-Siwaga, Jordan) a mineral with bredigitestoichiometry was observed in association with ariegilatite (Fig. 5 as well as Galuskin et al. 2018), which contains about 7 wt. $\%$ of $\mathrm{BaO}$ (see Table 5). This Ba-bearing bredigite belongs to the minerals of early clinker-like associations including larnite, fluorapatite, gehlenite, fluormayenite and spinel (Fig. 5). Ariegilatite, $\mathrm{BaCa}_{12}\left(\mathrm{SiO}_{4}\right)_{4}\left(\mathrm{PO}_{4}\right)_{2} \mathrm{~F}_{2} \mathrm{O}$, an 


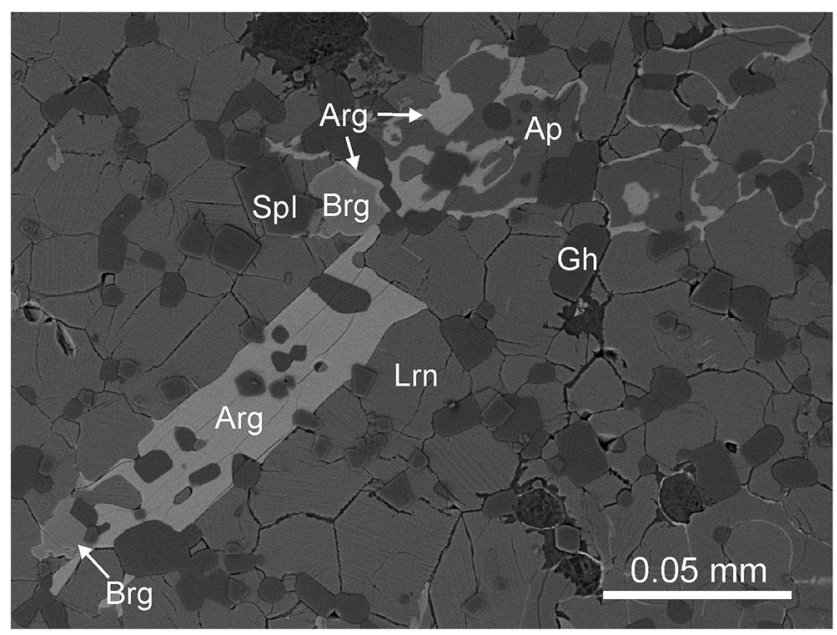

Fig. 5 Larnite rock from Jordan with Ba-bearing bredigite. Ap = fluorapatite, $\operatorname{Arg}=$ ariegilatite, $\mathrm{Brg}=\mathrm{Ba}$-bearing bredigite, $\mathrm{Gh}=$ gehlenite, $\mathrm{Lrn}=$ larnite, $\mathrm{Spl}=$ spinel

intercalated antiperovskite, crystallizes at a later stage. It develops after fluorapatite and forms reaction rims on Ba-bearing bredigite (Fig. 5). Ba-bearing bredigite from Jordan has the following composition: $\left(\mathrm{Ba}_{0.632} \mathrm{~K}_{0.054} \mathrm{Sr}_{0.040} \mathrm{Na}_{0.041} \mathrm{Ca}_{0.233}\right)_{\Sigma 1} \mathrm{Ca}_{13}\left(\mathrm{Mg}_{1.867} \mathrm{Ca}_{0.105} \mathrm{M}-\right.$ $\mathrm{n} 0.025)_{\Sigma 1.997}\left(\mathrm{Si}_{7.713} \mathrm{P}_{0.167} \mathrm{Fe}^{3+}{ }_{0.055} \mathrm{Al}_{0.046} \mathrm{Ti}_{0.027}\right)_{\Sigma 8.008} \mathrm{O}_{32}$ (Table 5) close to $\sim \mathrm{Ba}_{0.7} \mathrm{Ca}_{13.3} \mathrm{Mg}_{2}\left(\mathrm{SiO}_{4}\right)_{8}$, i.e. it is an analogue of synthetic so-called "Ba-Ca-bredigite", $\mathrm{BaCaCa}{ }_{12} \mathrm{Mg}_{2}\left(\mathrm{SiO}_{4}\right)_{8}$ (Moseley and Glasser 1982).

Consequently, bredigite originally investigated as a $\mathrm{Ba}$ bearing phase from slags (Tilley and Vincent 1948) is still on the IMA List of Minerals (http://nrmima.nrm.se) with crystal chemical formula $(\mathrm{Ca}, \mathrm{Ba}) \mathrm{Ca}_{13} \mathrm{Mg}_{2}\left(\mathrm{SiO}_{4}\right)_{8}$. Bredigite should have an end-member formula $\mathrm{Ca}_{14} \mathrm{Mg}_{2}\left(\mathrm{SiO}_{4}\right)_{8}$ or $\mathrm{Ca}_{7} \mathrm{Mg}\left(\mathrm{SiO}_{4}\right)_{4}$, as all known natural bredigites contain negligible amounts of $\mathrm{Ba}$ as an impurity, as already emphasized by Sabine et al. in 1985. As shown in our recent structural study on bredigite, barium incorporation seems to be restricted to the cation site $\mathrm{Ca} / \mathrm{Ba} 1$ in $(0,0,0)$. As mentioned above, Ba-bearing synthetic bredigites with composition $\mathrm{Ba}_{2} \mathrm{Ca}_{12} \mathrm{Mg}_{2}\left(\mathrm{SiO}_{4}\right)_{8}$ have been prepared by Moseley and Glasser (1982), indicating that in this case both positions Ca1 and Ca2 (or X11 and $\mathrm{X} 12$, according to the nomenclature of Moore and Araki (1976)) should be probably involved in the Ba-Ca exchange. Due to the formal criteria of the CNMNC IMA "Ba-Cabredigite" with formula $(\mathrm{Ba}, \mathrm{Ca}) \mathrm{CaCa}_{12} \mathrm{Mg}_{2}\left(\mathrm{SiO}_{4}\right)_{8}$ could be approved as a new mineral species as $\mathrm{Ba}>\mathrm{Ca}$ at the $\mathrm{Ca} 1$-site. These criteria are met by Ba-bearing bredigite from Jordan. Unfortunately, the sample could not be investigated in more detail because of the small size of the crystals and its mineralogical rarity. In general, pyrometamorphic rocks of the Hatrurim Complex and also of other larnite-bearing pyrometamorphic rocks, the protoliths of which were carbonate-silicate sedimentary rocks enriched in barium, are potential sources of the new Ba-analogue of bredigite.
Acknowledgements We are grateful to Dr. Yevgeny Vapnik for organization of field works in the Negev Desert. The research leading to these results has received funding from the European Union's Horizon 2020 research and innovation programme under grant agreement no. 730872, project CALIPSOplus. The manuscript benefited from the helpful comments of an anonymous reviewer.

Funding information Open access funding provided by University of Innsbruck and Medical University of Innsbruck.

Publisher's note Springer Nature remains neutral with regard to jurisdictional claims in published maps and institutional affiliations.

Open Access This article is distributed under the terms of the Creative Commons Attribution 4.0 International License (http:// creativecommons.org/licenses/by/4.0/), which permits unrestricted use, distribution, and reproduction in any medium, provided you give appropriate credit to the original author(s) and the source, provide a link to the Creative Commons license, and indicate if changes were made.

\section{Appendix 1}

Table 6 Comparison between the corresponding positions in Pnnm (our nomenclature) and Pnn2 (labeling scheme according to Moore and Araki (1976))

\begin{tabular}{|c|c|c|c|}
\hline \multicolumn{2}{|c|}{ Model in Pnnm } & \multicolumn{2}{|l|}{ Model in Pnn2 } \\
\hline Atom & $\begin{array}{l}\text { Wyckoff- } \\
\text { position }\end{array}$ & Atom & $\begin{array}{l}\text { Wyckoff- } \\
\text { position(s) }\end{array}$ \\
\hline $\mathrm{Ca} / \mathrm{Ba} 1$ & $2 a$ & $\mathrm{X} 11$ & $2 a$ \\
\hline $\mathrm{Ca} 2$ & $2 b$ & $\mathrm{X} 12$ & $2 a$ \\
\hline $\mathrm{Ca} 3$ & $8 h$ & $\mathrm{X} 21 \& \mathrm{X} 22$ & $4 c \& 4 c$ \\
\hline $\mathrm{Ca} 4$ & $8 h$ & Y11 \& Y12 & $4 c \& 4 c$ \\
\hline $\mathrm{Ca} 5$ & $4 g$ & $\mathrm{Y} 21$ & $4 c$ \\
\hline $\mathrm{Ca} 6$ & $4 g$ & Y22 & $4 c$ \\
\hline $\operatorname{Mg} 1$ & $2 d$ & M11 & $2 b$ \\
\hline $\mathrm{Mg} 2$ & $2 c$ & M12 & $2 b$ \\
\hline Si1 & $8 h$ & Si11 \& Si22 & $4 c \& 4 c$ \\
\hline $\mathrm{Si} 2$ & $4 g$ & $\mathrm{Si} 33$ & $4 c$ \\
\hline $\mathrm{Si} 3$ & $4 g$ & $\mathrm{Si} 44$ & $4 c$ \\
\hline $\mathrm{O} 1$ & $8 h$ & O11-1 \& O12-1 m & $4 c \& 4 c$ \\
\hline $\mathrm{O} 2$ & $8 h$ & O11-1 m \& O12-1 & $4 c \& 4 c$ \\
\hline $\mathrm{O} 3$ & $8 h$ & O11-2 \& O12-2 & $4 c \& 4 c$ \\
\hline $\mathrm{O} 4$ & $8 h$ & O11-3 \& O12-3 & $4 c \& 4 c$ \\
\hline O5 & $8 h$ & $\mathrm{O} 21-1 \& \mathrm{O} 21-1 \mathrm{~m}$ & $4 c \& 4 c$ \\
\hline O6 & $4 g$ & $\mathrm{O} 21-2$ & $4 c$ \\
\hline $\mathrm{O} 7$ & $4 g$ & $\mathrm{O} 21-3$ & $4 c$ \\
\hline O8 & $8 h$ & $\mathrm{O} 22-1 \& \mathrm{O} 22-1 \mathrm{~m}$ & $4 c \& 4 c$ \\
\hline O9 & $4 g$ & $\mathrm{O} 22-2$ & $4 c$ \\
\hline $\mathrm{O} 10$ & $4 g$ & $\mathrm{O} 22-3$ & $4 c$ \\
\hline
\end{tabular}




\section{References}

Armbruster T, Lazic B, Gfeller F, Galuskin EV, Galuskina IO, Savelyeva VB, Zadov AE, Pertsev NN, Dzierżanowski P (2011) Chlorine content and crystal chemistry of dellaite from the Birkhin gabbro massif, eastern Siberia, Russia. Mineral Mag 75:379-394

Bentor, YK (ed) (1960) Lexique Stratigraphique International, Asie. Volume III, Section 10.2, Israel. Centre National de la Research Scientifique, Paris

Beus AA (1962) About the mechanism of REE-minerals idiomorphic crystals formation in replacement processes. Proc IMGRE 1061(7):61-64

Brown ID, Altermatt D (1985) Bond-valence parameters obtained from a systematic analysis of the Inorganic Crystal Structure Database. Acta Crystallogr B41:244-247

Capillas C, Tasci ES, de la Flor G, Orobengoa D, Perez-Mato JM, Aroyo MI (2011) A new computer tool at the Bilbao Crystallographic Server to detect and characterize pseudosymmetry. Z Kristallogr 226:186-196

Douglas AM (1952) X-ray investigations of bredigite. Mineral Mag 29: $875-884$

Essene E (1980) The stability of bredigite and other Ca-Mg-silicates. J Am Ceram Soc 63:464-466

Farrugia LJ (1999) WinGX suite for small-molecule single-crystal crystallography. J Appl Crystallogr 32:837-838

Galuskin EV, Galuskina IO, Gfeller F, Krüger B, Kusz J, Vapnik J, Dulski M, Dżierzanowski P (2016) Silicocarnotite, $\mathrm{Ca}_{5}\left[\left(\mathrm{SiO}_{4}\right)\left(\mathrm{PO}_{4}\right)\right]\left(\mathrm{PO}_{4}\right)$, a new 'old' mineral from the Negev Desert, Israel, and the ternesitesilicocarnotite solid solution: indicators of high-temperature alteration of pyrometamorphic rocks of the Hatrurim Complex, southern Levant. Eur J Mineral 28:105-123

Galuskin EV, Krüger B, Galuskina IO, Krüger H, Vapnik Y, Wojdyla JA, Murashko M (2018) New mineral with modular structure derived from Hatrurite from the pyrometamorphic rocks of the Hatrurim Complex: ariegilatite, $\mathrm{BaCa}_{12}\left(\mathrm{SiO}_{4}\right)_{4}\left(\mathrm{PO}_{4}\right)_{2} \mathrm{~F}_{2} \mathrm{O}$, from Negev Desert, Israel. Minerals 8:19

Galuskina IO, Vapnik Y, Lazic B, Armbruster T, Murashko M, Galuskin EV (2014) Harmunite $\mathrm{CaFe}_{2} \mathrm{O}_{4}$-a new mineral from the Jabel Harmun, West Bank, Palestinian Autonomy, Israel. Am Mineral 99:965-975

Galuskina IO, Krüger B, Galuskin EV, Armbruster T, Gazeev VM, Włodyka R, Dulski M, Dzierżanowski P (2015) Fluorchegemite, $\mathrm{Ca}_{7}\left(\mathrm{SiO}_{4}\right)_{3} \mathrm{~F}_{2}$, a new mineral from the edgrewitebearing endoskarn zone of an altered xenolith in ignimbrites from Upper Chegem Caldera, northern Caucasus, Kabardina-balkaria, Russia; occurrence, crystal structure, and new data on the mineral assemblages. Can Mineral 53:325-344

Geller YI, Burg A, Halicz L, Kolodny Y (2012) System closure during the combustion metamorphic "Mottled Zone" event, Israel. Chem Geol 334:25-36

Grapes R (2011) Pyrometamorphism, 2nd edn. Springer Heidelberg, Dordrecht, London New York

Gross S (1977) The mineralogy of the Hatrurim Formation, Israel. Bull Geol Surv Israel 70:1-80

Huang XH, Chang J (2008) Preparation of nanocrystalline bredigite powders with apatite-forming ability by a simple combustion method. Mater Res Bull 43:1615-1620

Ilyushin GD, Blatov VA (2002) Crystal chemistry of zirconosilicates and their analogs: topological classification of MT frame-works and suprapolyhedral invariants. Acta Crystallogr B58:198-218

Jantzen CM, Glasser FP, Lachowski EE (1984) Radioactive wastePortland cement systems: I, radionuclide distribution. J Am Ceram Soc 67:668-673

Jia YC, Qiao H, Zheng YH, Guo N, You HP (2012) Synthesis and photoluminescence properties of $\mathrm{Ce}^{3+}$ and $\mathrm{Eu}^{2+}$-activated
$\mathrm{Ca}_{7} \mathrm{Mg}\left(\mathrm{SiO}_{4}\right)_{4}$ phosphors for solid state lighting. Phys Chem Chem Phys 14:3537-3542

Joesten R (1976) High-temperature contact metamorphism of zoned calcsilicate nodules from a contact aureole, Christmas Mountains, Big Bend region, Texas. Am Mineral 61:776-781

Kato K, Saalfeld H (1968) Verfeinerung der Kristallstruktur von $\mathrm{CaO} \cdot 6 \mathrm{Al}_{2} \mathrm{O}_{3}$. Neues Jb Miner Abh 109:192-200

Kolodny Y, Gross S (1974) Thermal metamorphism by combustion of organic matter: isotopic and petrological evidence. J Geol 82: 489-506

Kolodny Y, Burg A, Sneh A (2013) Comment on "Combustion metamorphism in the Nabi Musa dome: new implications for a mud volcano origin of the Mottled Zone, Dead Sea area”, by E. Sokol, I. Novikov, S. Zateeva, Ye Vapnik, R. Shagam and O. Kozmenko, Basin Research (2010), 22, 414-438. Basin Res 25:112-114

Kriskova L, Eroli M, Iacobescu R, Onisei O, Vecchiocattivi F, Pontikes Y (2018) Transformation of stainless steel slag toward a reactive cementitious binder. J Am Ceram Soc 101:1727-1736

Lee KH, Park SH, Yoon HS, Kim YI, Jang HG, Im WB (2012) Bredigite-structure orthosilicate phosphor as a green component for white LED: the structural and optical properties. Opt Express 20:6248-6257

Lin HC, Foster WR (1975) Stability relations of Bredigite (5CaO.MgO. $3 \mathrm{SiO}_{2}$ ). J Am Ceram Soc 58:73

Matthews A, Gross S (1980) Petrologic evolution of the Mottled Zone (Hatrurim) metamorphic complex of Israel. Isr J Earth Sci 29:93-106

Momma K, Izumi F (2011) VESTA 3 for three-dimensional visualization of crystal, volumetric and morphology data. J Appl Crystallogr 44: $1272-1276$

Moore PB (1973) Bracelets and pinwheels: a topological-geometrical approach to the calcium orthosilicate and alkali sulfate structures. Am Mineral 58:32-42

Moore PB, Araki T (1972) Atomic arrangement of merwinite, $\mathrm{Ca}_{3} \mathrm{Mg}\left[\mathrm{SiO}_{4}\right]_{2}$, an unusual dense-packed structure of geophysical interest. Am Mineral 57:1355-1374

Moore PB, Araki T (1976) The crystal structure of bredigite and the genealogy of some alkaline earth orthosilicates. Am Mineral 61: 74-87

Moseley D, Glasser FP (1981) Identity, composition and stability of bredigite phase T. Cem Concr Res 11:559-565

Moseley D, Glasser FP (1982) Properties and composition of bredigitestructures phases. J Mater Sci 17:2736-2740

Novikov I, Vapnik Y, Safonova I (2013) Mud volcano origin of the Mottled Zone, south Levant. Geosci Front 4:597-619

Rahmati M, Fahti M, Ahmadian M (2018) Preparation and structural characterization of bioactive bredigite $\left(\mathrm{Ca}_{7} \mathrm{MgSi}_{4} \mathrm{O}_{16}\right)$ nanopowder. J Alloys Compd 732:9-15

Rigaku Oxford Diffraction (2015) CrysAlisPRO, Version 1.1713843

Robinson R, Gibbs GV, Ribbe PH (1971) Quadratic elongation: a quantitative measure of distortion in coordination polyhedra. Science $172: 567-570$

Saalfeld H (1974) Kristallographische Untersuchungen über die Verbindung $\mathrm{Ca}_{7} \mathrm{MgSi}_{4} \mathrm{O}_{16}$ (Phase $\mathrm{T}$ ) im System $\mathrm{Ca}_{2} \mathrm{SiO}_{4}$ $\mathrm{Ca}_{3} \mathrm{Mg}\left(\mathrm{SiO}_{4}\right)_{2}$. Ber Dtsch Keram Ges 51:295-298

Sabine PA, Styles MT, Young BR (1985) The nature and paragenesis of natural bredigite and associated minerals from Carneal and Scawt Hill, Co. Antrim. Mineral Mag 49:663-670

Schlaudt CM, Roy DM (1966) The join $\mathrm{Ca}_{2} \mathrm{SiO}_{4}-\mathrm{CaMgSiO}_{4}$. J Am Ceram Soc 49:430-432

Sharygin VV, Sokol EV, Vapnik Y (2008) Minerals of the pseudobinary perovskite-brownmillerite series from combustion metamorphic larnite rocks of the Hatrurim Formation (Israel). Russ Geol Geophys 49:709-726

Sheldrick GM (2008) A short history of SHELX. Acta Crystallogr A64: $112-122$ 
Sokol E, Novikov I, Zateeva S, Vapnik Y, Shagam R, Kozmenko O (2010) Combustion metamorphism in the Nabi Musa dome: new implications for a mud volcanic origin of the Mottled Zone, Dead Sea area. Basin Res 22:414-438

Sun WZ, Pang R, Li HF, Jia YL, Zhang S, Jiang LH, Li CY (2015) Synthesis and photoluminescence properties of novel red-emitting $\mathrm{Ca}_{14} \mathrm{Mg}_{2}\left(\mathrm{SiO}_{4}\right)_{8}: \mathrm{Eu}^{3+} / \mathrm{Sm}^{3+}$ phosphors. J Rare Earths 33:814-819

Tilley CE, Vincent HCG (1948) The occurrence of an orthorhombic hightemperature form of $\mathrm{Ca}_{2} \mathrm{SiO}_{4}$ (bredigite) in the Scawt Hill contactzone and as a constituent of slags. Mineral Mag 28:255-271

Vapnik Y, Novikov I (2013) Reply to Comment of Y. Kolodny, A. Burg, and A. Sneh on Combustion metamorphism in the Nabi Musa dome: new implications for a mud volcano origin of the Mottled Zone, Dead Sea area, by E. Sokol, I. Novikov, S. Zateeva, Ye. Vapnik, R. Shagam and O. Kozmenko, Basin Research (2010) 22, 414 438. Basin Res 25:115-120

Vapnik Y, Vardi J (2013) Combustion metamorphic stone tools, Hatrurim Basin, Israel. 192-204. In: Stracher GB, Prakash A, Sokol EV (eds)
Coal and Peat Fires: A Global Perspective, Volume 2. Elsevier, Amsterdam, The Netherlands

Vapnik Y, Sharygin VV, Sokol EV, Shagam R (2007) Paralavas in a combustion metamorphic complex: Hatrurim Basin, Israel. Rev Eng Geol 18:1-21

Wang Z, Sun Y, Sridhar S, Zhang M, Guo M, Zhang Z (2015) Selective crystallization behaviour of $\mathrm{CaO}-\mathrm{SiO}_{2}-\mathrm{Al}_{2} \mathrm{O}_{3}-\mathrm{MgO}-\mathrm{FeO}-\mathrm{P}_{2} \mathrm{O}_{5}$ steelmaking slags modified through $\mathrm{P}_{2} \mathrm{O}_{5}$ and $\mathrm{Al}_{2} \mathrm{O}_{3}$. Metall Mater Trans B46:2246-2254

Wilson AJC (1992) International Tables for Crystallography, Volume C. In: Mathematical, physical and chemical tables, 1st edn. Kluwer Academic Publishers, Dordrecht, Boston, London

Wu C, Chang J, Wang J, Ni S, Zhai W (2005) Preparation and characteristics of a calcium magnesium silicate (bredigite) bioactive ceramic. Biomaterials 26:2925-2931

Zhang J, Jiang C (2014) Luminescence properties of $\mathrm{Ca}_{14} \mathrm{Mg}_{2}\left(\mathrm{SiO}_{4}\right)_{8}$ : $\mathrm{Eu}^{2+}$ from various $\mathrm{Eu}^{2+}$ sites for white-light-emitting diodes. Mater Res Bull 60:467-473 